\title{
Development and Validation of HPLC-PDA Assay method of Frangula emodin
}

\author{
Deborah Duca* and Claude Farrugia
}

Chemistry Department, University of Malta, Msida, Malta MSD2080

\begin{abstract}
Frangula emodin, (1,3,8-trihydroxy-6-methyl-anthraquinone), is one of the anthraquinone derivatives found abundantly in the roots and bark of a number of plant families traditionally used to treat constipation and haemorrhoids. The present study describes the development and subsequent validation of a specific assay HPLC method for emodin. The separation was achieved on a Waters Symmetry C18, $4.6 \times 250 \mathrm{~mm}, 5 \mu \mathrm{m}$ particle size, column at a temperature of $35^{\circ} \mathrm{C}$, with UV detection at 287 and $436 \mathrm{~nm}$. An isocratic elution mode consisting of $0.1 \%$ formic acid and $0.01 \%$ trifluoroacetic acid as the aqueous mobile phase, and methanol was used. The method was successfully and statistically validated for linearity, range, precision, accuracy, specificity and solution stability.
\end{abstract}

Keywords: Emodin; anthraquinone; HPLC; assay; development; validation.

\section{Introduction}

A significant number of herbal medicinal products, despite their long tradition, do not fulfill the requirements imposed by European Union (EU) Directive 2004/24/EC on Traditional Herbal Medicinal Products, introduced in $2005^{1}$, which states that companies manufacturing herbal medicinal drugs must show proof of the drug's efficacy and pharmaceutical quality. To maintain these products on the market, companies must supply scientific evidence that proves the quality, safety and efficacy of their products. Frangula emodin, (1,3,8trihydroxy-6-methyl-anthraquinone) (Fig. 1), is one of the anthraquinone derivatives found abundantly in the roots and bark of Fabaceae (Cassia spp.), Polygonaceae (Rheum, Rumex and Polygonum spp.) and Rhamnaceae (Rhamnus and Ventilago spp.). These plants have been used traditionally in the Eastern world for their purgative effects to treat constipation and haemorrhoid 2, 3. The laxative properties have been attributed to the active constituents of these plants, one of which is emodin.<smiles>Cc1cc(O)c2c(c1)C(=O)c1cc(O)cc(O)c1C2=O</smiles>

Figure 1. Emodin structure
Studies have shown emodin to display a number of biological activities such as anti-microbial ${ }^{4}$, immunosuppressive $^{5}$, anti-diabetic ${ }^{6}$ and antiinflammatory activities ${ }^{7}, 8$. Moreover, emodin is thought to have anti-tumor properties. Studies have been performed both in vitro and in vivo, and results have shown emodin to have potential as a cytotoxic agent against a variety of human cancers including lung cancer ${ }^{9}$, liver cancer ${ }^{10}$, and gastric cancer ${ }^{11}$.

Various methods have been reported in the literature for the analysis of emodin in a mixture of anthraquinones including thin layer chromatography $^{12}$, high performance liquid chromatography (HPLC) with ultraviolet-visible $(\mathrm{UV}-\mathrm{Vis})^{13}$, photodiode array (PDA) ${ }^{14}$, fluorescence $^{15}$ and mass spectrometric $(\mathrm{MS})^{16}$ detection. The disadvantage of running methods that were developed for the simultaneous determination of a number of anthraquinones is that in order to achieve sufficient separation between the peaks, they usually incorporate long run times. For routine analysis of emodin, a simple and rapid analytical method is preferred. Few reports of a specific validated UV spectrophotometric method for the assay quantification of Frangula emodin have been published to date ${ }^{17,}{ }^{18}$. This study focused on supplying chromatographic information on the emodin molecule to meet the requirements imposed by the aforementioned directive, and enable further research and product development. The first objective was to establish the physicochemical properties of emodin that were relevant to the development of a chromatographic method in terms 
of sample preparation and HPLC analysis. Secondly, an assay HPLC method capable of identifying and quantifying emodin in the presence of related substances was developed and subsequently validated in accordance with the International Conference on Harmonisation (ICH) guideline $\mathrm{Q} 2(\mathrm{R} 1)$ relating to the validation of analytical procedures ${ }^{19}$.

\section{Experimental Section}

\section{Instrumentation}

A Waters Alliance 2695 Separations Module, consisting of an on-line degasser, quaternary pump, thermostatted sample compartment, auto-sampler, column heater/cooler and Waters 2998 PDA detector was employed. Data were acquired and processed using the Waters Empower 2.0 software. A C18 reversed phase column Waters Symmetry C18, $4.6 \times$ $250 \mathrm{~mm}, 5 \mu \mathrm{m}$ particle size, was used for the separation. A Bruker AM250 Nuclear magnetic resonance (NMR) spectrophotometer fitted with ${ }^{1} \mathrm{H}$ and ${ }^{13} \mathrm{C}$ probe of frequency $250.1 \mathrm{MHz}$ for ${ }^{1} \mathrm{H}$ and $62.9 \mathrm{MHz}$ for the ${ }^{13} \mathrm{C}$ probe with the corresponding software Bruker Aspect 3000 pc using $16 \mathrm{~K}$ for ${ }^{1} \mathrm{H}$ NMR was used.

\section{Software}

ACD Chemsketch software version 10.00 Calculator Plugins were used to predict $\mathrm{p} K_{\mathrm{a}}$ values and generate $\mathrm{p} K_{\mathrm{a}}$ plots, Marvin 6.1.6, 2014, ChemAxon (http://www.chemaxon.com). Statistical analysis was performed using Microsoft Excel and SPSS 20.0 for Windows.

\section{Chemicals and Reagents}

HPLC gradient grade methanol and trifluoroacetic acid (TFA) (> 99.0\% purity) were purchased from Sigma Aldrich. Formic acid (98\% purity) was obtained from Fischer Scientific (UK.). Deionized water was purified using the ELGA Pure Lab Classic System with $0.2 \mu \mathrm{m}$ filter, TOC 1 to 3 $\mathrm{ppb}$ and resistivity $\geq 18.2 \mathrm{M} \Omega-\mathrm{cm}$. The emodin working standard utilized during this research project was obtained from Applichem, Germany with the item code A2056. It was certified as being of HPLC grade and extracted from Rhamnus frangula. This working standard was used as the sample throughout the project. The reference standard of emodin of item code E7881 was obtained from Sigma Aldrich. The standard was extracted from Frangula bark and its HPLC purity was stated as being $96.10 \%$.

\section{Standard Solution}

Working and reference standard solutions of emodin were prepared by dissolving accurately weighed amounts of emodin standard in $100 \%$ methanol, followed by 15 minute sonication and topping up to the mark to give a final concentration of $0.5 \mathrm{mg} / \mathrm{mL}$. A similar standard concentration was selected in multiple studies ${ }^{20,21,22}$. The solutions were stored at $4{ }^{\circ} \mathrm{C}$.

\section{Method Scouting and Development}

Several HPLC methods have been developed and validated for the analysis of anthraquinones. These methods primarily differ in the type of column used, mobile phase, flow rate and their applications. A literature survey was first performed in search of HPLC methods that included emodin as one of the analytes. Most methods were developed for the separation and determination of mixtures of anthraquinones present in various herbal extracts. Additionally they incorporated rather long runtimes to allow for the separation of the various components.

Methods that included phosphate buffers ${ }^{23}, 24$ were excluded as phosphate buffers are incompatible with certain detectors, including mass spectrometry. Hence in order to allow the rapid transfer of methods from UV detection to MS detection, the chromatographic parameters were chosen to be both UV and MS compatible. Preliminary testing was performed to establish the $\mathrm{p} K_{\mathrm{a}}$ of the emodin molecule and also to identify the UV wavelengths at which the emodin molecule absorbed most intensely.

The shortlisted methods (Systems 1, 2 and 3), which were selected based upon the results of the preliminary testing, were attempted on the Waters Alliance HPLC injecting only the emodin working standard. The resultant chromatograms were examined for sensitivity, efficiency and separation characteristics. The retention time, peak area, United States Pharmacopeia (USP) plate count and USP tailing were measured. The method that produced the best results for the emodin peak (System 3) was further optimized for column temperature, detection wavelength and mobile phase composition to obtain specificity of the emodin peak in the shortest run time possible (Systems 4, 5 and 6). A small quantity of TFA was incorporated into the mobile phase to sharpen peaks and as a result improve peak efficiency and resolution. In order to determine the optimal TFA concentration that was compatible with the emodin molecule without exceeding the $\mathrm{pH}$ limit recommended by the column, two concentrations of TFA were analyzed on the HPLC (Systems 7 and 8) and the resultant chromatograms were examined for efficiency of peaks. Specificity and the optimal detection wavelength were determined by performing peak purity testing using the PDA detector. The optimized method was then validated in accordance to the International Conference of Harmonization (ICH) guideline Q2(R1) ${ }^{19}$. 
Table 1. Summary of HPLC methods investigated during method scouting and development.

\begin{tabular}{|c|c|c|c|c|c|c|c|}
\hline System & $\begin{array}{l}\text { Mobile Phase } \\
\text { Constituents } \\
\text { (A:B) }\end{array}$ & $\begin{array}{l}\text { Isocratic/Gradient } \\
\text { Profile }\end{array}$ & $\begin{array}{l}\text { Flow } \\
\text { Rate } \\
(\mathrm{mL} / \mathrm{min})\end{array}$ & $\begin{array}{l}\text { Column } \\
\text { Temp. } \\
\left({ }^{\circ} \mathrm{C}\right)\end{array}$ & $\begin{array}{l}\text { UV } \\
\lambda \\
(\mathbf{n m})\end{array}$ & $\begin{array}{l}\text { Retentio } \\
\text { n Time } \\
\text { (mins) }\end{array}$ & Reference \\
\hline 1 & $\begin{array}{l}\text { Water: } \\
\text { methanol }\end{array}$ & $\begin{array}{l}\text { Gradient } \\
0 \text { mins: } 55 \% \mathrm{~A} \\
0 \text { to } 6 \mathrm{~min}: 55 \% \mathrm{~A} \\
6 \text { to } 9 \text { min: } 25 \% \mathrm{~A} \\
9 \text { to } 18 \mathrm{~min}: 0 \% \mathrm{~A} \\
18 \text { to } 25 \mathrm{~min}: 0 \% \mathrm{~A}\end{array}$ & 1.0 & 25 & 436 & 21.090 & 18 \\
\hline 2 & $\begin{array}{l}0.1 \%(\mathrm{v} / \mathrm{v}) \\
\text { Formic acid : } \\
\text { methanol }\end{array}$ & $\begin{array}{l}\text { Gradient } \\
0 \text { mins: } 28 \% \mathrm{~A} \\
0 \text { to } 5 \mathrm{~min}: 20 \% \mathrm{~A} \\
5 \text { to } 10 \mathrm{~min}: 15 \% \mathrm{~A} \\
10 \text { to } 14 \mathrm{~min}: 10 \% \mathrm{~A}\end{array}$ & 1.0 & 50 & N/A & 21.871 & 25 \\
\hline 3 & $\begin{array}{l}0.1 \%(\mathrm{v} / \mathrm{v}) \\
\text { Formic acid : } \\
\text { methanol }\end{array}$ & $\begin{array}{l}\text { Isocratic } \\
15 \% \mathrm{~A}: 85 \% \mathrm{~B}\end{array}$ & 1.0 & 25 & 254 & 9.629 & 26 \\
\hline 4 & $\begin{array}{l}0.1 \%(\mathrm{v} / \mathrm{v}) \\
\text { Formic Acid : } \\
\text { methanol }\end{array}$ & $\begin{array}{l}\text { Gradient } \\
0 \text { mins: } 28 \% \mathrm{~A} \\
0 \text { to } 10 \mathrm{~min}: 28 \% \mathrm{~A} \\
10 \text { to } 21 \mathrm{~min}: 15 \% \mathrm{~A} \\
21 \text { to } 30 \mathrm{~min}: 10 \% \mathrm{~A}\end{array}$ & 1.0 & 35 & 254 & 19.408 & $\begin{array}{l}\text { Optimization of } \\
\text { System } 2\end{array}$ \\
\hline 5 & $\begin{array}{l}0.1 \%(\mathrm{v} / \mathrm{v}) \\
\text { Formic Acid : } \\
\text { methanol }\end{array}$ & $\begin{array}{l}\text { Gradient } \\
0 \text { mins: } 55 \% \mathrm{~A} \\
0 \text { to } 6 \text { min: } 55 \% \mathrm{~A} \\
6 \text { to } 9 \text { min: } 25 \% \mathrm{~A} \\
9 \text { to } 18 \mathrm{~min}: 0 \% \mathrm{~A} \\
18 \text { to } 25 \mathrm{~min}: 0 \% \mathrm{~A}\end{array}$ & 1.0 & 35 & $\begin{array}{l}254 \\
436\end{array}$ & 17.051 & $\begin{array}{l}\text { Optimization of } \\
\text { Systems } 1 \text { and } 2\end{array}$ \\
\hline 6 & $\begin{array}{l}0.1 \%(\mathrm{v} / \mathrm{v}) \\
\text { Formic Acid : } \\
\text { methanol }\end{array}$ & $\begin{array}{l}\text { Isocratic } \\
10 \% \mathrm{~A}: 90 \% \mathrm{~B}\end{array}$ & 1.0 & 35 & $\begin{array}{l}254 \\
436\end{array}$ & 6.425 & $\begin{array}{l}\text { Optimization of } \\
\text { System } 3\end{array}$ \\
\hline 7 & $\begin{array}{l}0.1 \% \text { TFA : } \\
\text { methanol }\end{array}$ & $\begin{array}{l}\text { Isocratic } \\
10 \% \mathrm{~A}: 90 \% \mathrm{~B}\end{array}$ & 1.0 & 35 & $\begin{array}{l}254 \\
436\end{array}$ & 5.985 & $\begin{array}{l}\text { Investigating the } \\
\text { effect of TFA }\end{array}$ \\
\hline 8 & $\begin{array}{l}0.01 \% \text { TFA : } \\
\text { methanol }\end{array}$ & $\begin{array}{l}\text { Isocratic } \\
10 \% \mathrm{~A}: 90 \% \mathrm{~B}\end{array}$ & 1.0 & 35 & $\begin{array}{l}254 \\
436\end{array}$ & 5.891 & $\begin{array}{l}\text { Investigating the } \\
\text { effect of TFA }\end{array}$ \\
\hline 9 & $\begin{array}{l}0.01 \% \text { TFA } \\
0.1 \% \text { formic } \\
\text { acid : methanol }\end{array}$ & $\begin{array}{l}\text { Isocratic } \\
10 \% \mathrm{~A}: 90 \% \mathrm{~B}\end{array}$ & 1.0 & 35 & $\begin{array}{l}254 \\
436\end{array}$ & 5.905 & $\begin{array}{l}\text { Chosen } \\
\text { optimized } \\
\text { chromatographic } \\
\text { conditions }\end{array}$ \\
\hline
\end{tabular}

\section{Results and Discussion}

\section{Preliminary study of the emodin molecule}

The $\mathrm{p} K_{\mathrm{a}}$ of emodin generated using ACD Chemsketch software version 10.00 , was found to be 6.39 with an error of 0.2 . This value appears to be a combination of the dissociation constants $\mathrm{p} K_{\mathrm{a} 1}$ and $\mathrm{p} K_{\mathrm{a} 2}$ which were reported as being 5.70 and 7.94 respectively ${ }^{27}$. From this information it was deduced that an acidic mobile phase was preferable with a $\mathrm{pH}$ lower than 4.70 in order to have the emodin in a single ionization form. Due to the molecule's acidic functionality, the emodin would be in its unionized form at $\mathrm{pH}$ 's lower than 4.70 and moreover in a 'robust $\mathrm{pH}$ zone' which is vital for reproducible retention times.
The UV spectrum of the emodin working standard dissolved in methanol (Fig. 2) gave a preliminary idea of the wavelengths that showed the highest absorption for emodin which is an important factor to consider when deciding on the detection wavelength for the HPLC method. A spectrum of pure methanol was also included as a blank to ensure that no interferences from the diluent were present. The electronic absorption spectrum of emodin was measured in methanol at room temperature in the wavelength region 200 to $700 \mathrm{~nm}$. Five prominent bands were identified with maxima at 221, 252, 265, 288 and $435 \mathrm{~nm}$. The spectrum matched the spectrum reported by Marković et al. ${ }^{28}$. The broad band at $435 \mathrm{~nm}$ was reported to have a dominant charge transfer character in the same research study. 


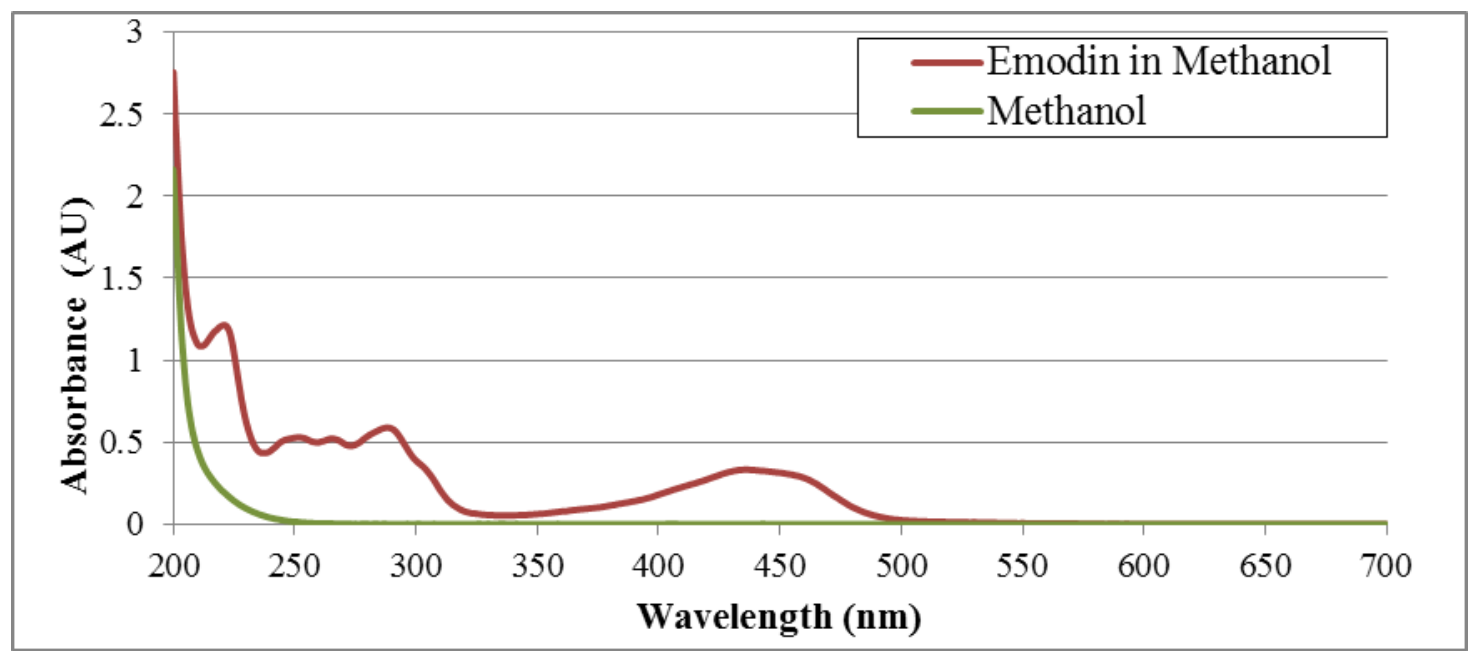

Figure 2. UV-VIS spectrum of the emodin working standard in methanol using the Shimadzu UV-Vis spectrophotometer

\section{Method Development and Optimisation}

The optimal chromatographic conditions for the HPLC assay method for emodin are listed in Table.
2, Full and Expanded integrated chromatograms are displayed in Fig. 3 (A) and 3 (B).

Table 2. HPLC method parameters for the assay determination of emodin (System 9).

\begin{tabular}{|l|l|}
\hline Column & Waters Symmetry C18 250 x $4.6 \mathrm{~mm}, 5 \mu \mathrm{m}$ \\
\hline Mobile Phase & $\begin{array}{l}\text { Mobile Phase A: 0.01\% (v/v) TFA 0.1\% (v/v) formic acid } \\
\text { Mobile Phase B: } 100 \% \text { methanol HPLC grade }\end{array}$ \\
\hline Isocratic Profile & $10 \% \mathrm{MP}$ A : 90\% MP B \\
\hline Flow rate & $1.00 \mathrm{~mL} / \mathrm{min}$ \\
\hline Run Time & $15 \mathrm{minutes}$ \\
\hline Column Temperature & $35^{\circ} \mathrm{C}$ \\
\hline Sample Temperature & $4{ }^{\circ} \mathrm{C}$ \\
\hline Injection volume & $10 \mu \mathrm{L}$ \\
\hline UV detection wavelength & $287 \mathrm{~nm}, 436 \mathrm{~nm}$ and PDA Analysis $(210-500 \mathrm{~nm})$ \\
\hline Diluent & $100 \% \mathrm{HPLC}$ grade methanol \\
\hline Solution Filters & $0.45 \mu \mathrm{m}$ Pall GHP filters of code PN-4562 \\
\hline Test concentration & $0.5 \mathrm{mg} / \mathrm{mL}$ \\
\hline
\end{tabular}

On injecting the working standard, four peaks were eluted, one of which was more significant than the other three (Fig. 3). An injection of the reference standard of emodin indicated that the emodin peak was expected to elute at approximately 5.9 minutes. The peaks were labelled emodin, Unknown 1, 2 and 3 , all of which had excellent USP Tailing and USP plate count. The total run time of the system was 15 minutes which was considerably short. The chromatograms at $287 \mathrm{~nm}$ and $436 \mathrm{~nm}$ were visually identical so only chromatograms for the $436 \mathrm{~nm}$ wavelength are reported in this paper.

The method was run at dual wavelengths, 287 $\mathrm{nm}$ and $436 \mathrm{~nm}$, as they provided two distinctive insights into the performance of the analytical method. Investigation at $287 \mathrm{~nm}$, albeit having slight interferences from the mobile phase additives which may reduce the robustness of the method, offers a broader view of the components in the sample since most samples absorb at low wavelengths. On the other hand, selecting a longer wavelength is more selective towards the drug substance and picks up less system peaks and degradation products. The result of both wavelengths was reported to relate both perspectives (Table. 3 ).

The peaks were all baseline resolved from each other with a resolution larger than 3.0 for all the four peaks. Nevertheless peak purity testing was performed using the Waters Empower software to ensure that the peaks were also spectrally pure. A max plot for a standard injection analysed using system 9 (Tables. 1 and 2) was generated and the results are displayed in Table. 4. The results indicated the emodin peak was spectrally pure, with 
purity angle values lower than the purity threshold. Thus, the method was specific for emodin as per ICH criteria for specificity, namely, "the ability of the method to unequivocally assess the analyte in the presence of other components that may be expected to be present for example, impurities, degradation products and matrix components". The first two peaks in the chromatogram (Fig. 3) were spectrally impure (Table. 4) and were hence referred to as
Unknown 1 and Unknown 2. The second major peak in the system, at retention time 10.222 minutes (Table 4) was labelled Unknown 3, and with purity angle values below the threshold, was also found to be spectrally pure. All three unknown peaks were most likely impurities or matrix components. The next section describes tests that were performed in an attempt to identify the unknown peaks.
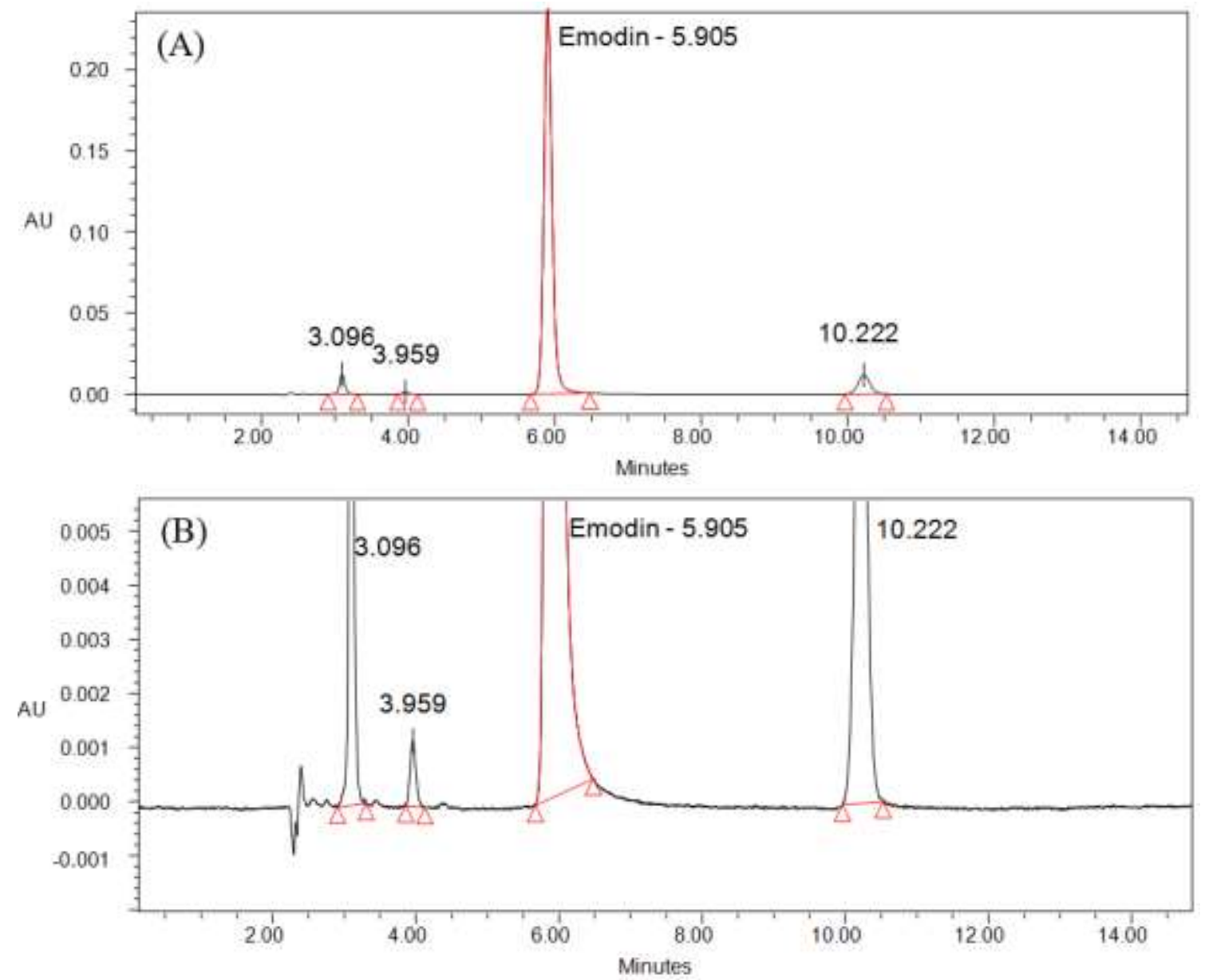

Figure 3. Full (A) and expanded (B) chromatograms obtained using chromatographic System 9 at $436 \mathrm{~nm}$; Injection peak at 2.361 minutes.

Table 3. Chromatographic profile obtained for the optimised HPLC assay method for emodin at $254 \mathrm{~nm}$ and $436 \mathrm{~nm}$.

\begin{tabular}{|c|c|c|c|c|c|c|}
\hline \multicolumn{7}{|c|}{ At $287 \mathrm{~nm}$} \\
\hline $\begin{array}{l}\text { Peak } \\
\text { number }\end{array}$ & $\begin{array}{l}\text { Retention time } \\
\text { (mins) }\end{array}$ & Peak name & $\begin{array}{l}\text { Area } \\
\left(\mu v^{*} \sec \right)\end{array}$ & $\%$ Area & $\begin{array}{l}\text { USP Plate } \\
\text { count }\end{array}$ & USP tailing \\
\hline 1 & 3.096 & Unknown 1 & 101984 & 2.77 & 10111 & 1.160 \\
\hline 2 & 3.959 & Unknown 2 & 10295 & 0.28 & 10752 & 1.150 \\
\hline 3 & 5.905 & Emodin & 17366864 & 91.36 & 15941 & 1.170 \\
\hline 4 & 10.222 & Unknown 3 & 205965 & 5.59 & 18908 & 1.021 \\
\hline \multicolumn{7}{|c|}{ At 436nm } \\
\hline $\begin{array}{l}\text { Peak } \\
\text { number }\end{array}$ & $\begin{array}{l}\text { Retention time } \\
\text { (mins) }\end{array}$ & Peak name & $\begin{array}{l}\text { Area } \\
\left(\mu v^{*} \text { sec }\right)\end{array}$ & $\%$ Area & $\begin{array}{ll}\text { USP } & \text { Plate } \\
\text { count } & \end{array}$ & USP tailing \\
\hline 1 & 3.096 & Unknown 1 & 59603 & 2.89 & 10115 & 1.150 \\
\hline 2 & 3.959 & Unknown 2 & 6959 & 0.34 & 11719 & 1.203 \\
\hline 3 & 5.905 & Emodin & 1863743 & 90.34 & 15958 & 1.168 \\
\hline 4 & 10.222 & Unknown 3 & 132767 & 6.44 & 18937 & 1.020 \\
\hline
\end{tabular}


Table 4. PDA Peak Purity Output obtained using chromatographic System 9

\begin{tabular}{|l|l|l|l|l|l|}
\hline $\begin{array}{c}\text { Peak } \\
\text { number }\end{array}$ & \multicolumn{1}{|c|}{$\begin{array}{c}\text { Retention time } \\
(\mathbf{m i n})\end{array}$} & \multicolumn{1}{|c|}{ Peak name } & Purity angle & Purity threshold & Spectral status \\
\hline 1 & 3.096 & Unknown 1 & 2.193 & 0.469 & Impure \\
\hline 2 & 3.959 & Unknown 2 & 15.182 & 2.417 & Impure \\
\hline 3 & 5.905 & Emodin & 0.217 & 0.261 & Pure \\
\hline 4 & 10.222 & Unknown 3 & 0.225 & 0.402 & Pure \\
\hline
\end{tabular}

\section{Identification of impurities}

Identification of the unknown peaks that had eluted in the optimised system was attempted. The UV absorption spectra for the four individual peaks (Fig. 4) were extracted using the Empower PDA software.

On comparing the four absorption spectra, several similarities were observed. The peaks and troughs of the spectra, as well as the $\lambda_{\max }$ values, were similar to each other suggesting that all three unknown peaks were anthraquinones, albeit with different side groups.
A common observation made from most systems that were investigated is that one of the unknown peaks that eluted after emodin was always present in the approximate range of 6 to $7.5 \%$ area of the total peak area. This was a good indication that the peak in these systems represented the same impurity or degradation product. Since this component was the second most abundant component in the sample it was important to attempt to identify its structure. 


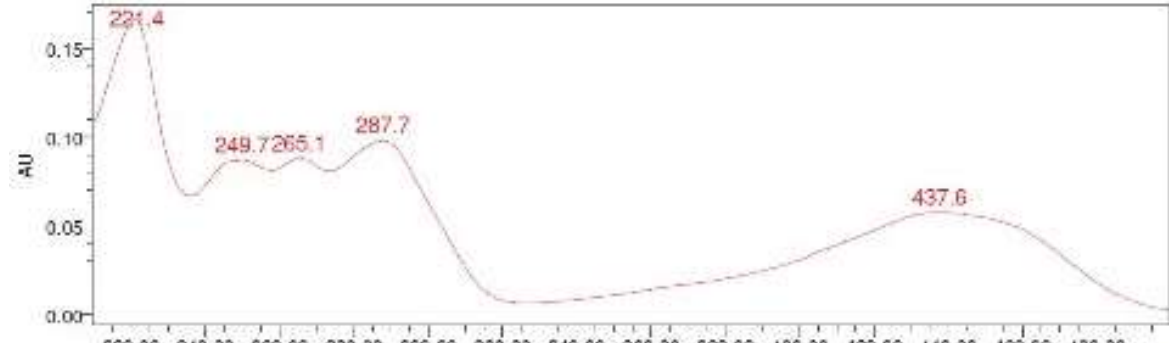

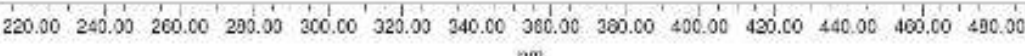
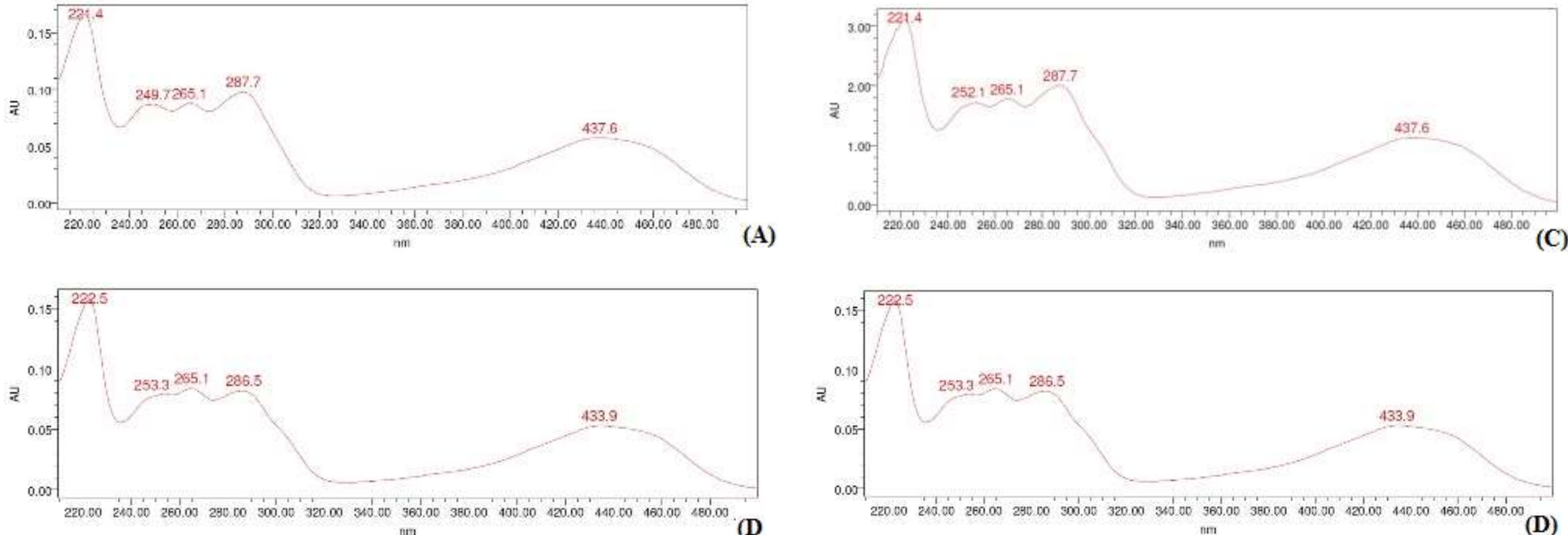

Figure 4. Absorption spectra generated using PDA software of (A) peak at retention time 3.097 minutes (Unknown 1); (B) peak at retention time 3.960 minutes (Unknown 2); (C) emodin peak at retention time 5.905 minutes; (D) peak at retention time 10.222 minutes (Unknown 3) 
The ${ }^{1}$ HNMR spectrum of the emodin working standard was acquired on a Bruker AM250NMR spectrophotometer. Analysis was carried out at room temperature using $5 \mathrm{mg}$ of emodin in approximately $0.8 \mathrm{~mL}$ of deuterated dimethyl sulfoxide solvent. The result obtained is documented below:

${ }^{1} \mathrm{H}$ NMR (DMSO, 250.1MHz) $\delta: 12.12(1 \mathrm{H}, \mathrm{s},-\mathrm{OH})$, $12.07(1 \mathrm{H}, \mathrm{s},-\mathrm{OH}), 12.04(1 \mathrm{H}, \mathrm{s},-\mathrm{OH}), 7.47(1 \mathrm{H}, \mathrm{s}$, $\mathrm{H}-4), 7.16$ (1H, s, H-2), $7.10(1 \mathrm{H}, \mathrm{d}, \mathrm{H}-5), 6.57(1 \mathrm{H}$, d, H-7), $3.93\left(3 \mathrm{H}, \mathrm{s},-\mathrm{OCH}_{3}\right), 2.41\left(3 \mathrm{H}, \mathrm{s}, \mathrm{CH}_{3}\right)$

The NMR spectrum of emodin working standard matched the data reported by Chu et al. ${ }^{29}$ and Guo et al. ${ }^{30}$ with the exception of a signal at $3.93 \mathrm{ppm}$. The $3.93 \mathrm{ppm}$ signal is typical of the three hydrogens of the methoxy group. The integration ratio of the two signals at 3.93 and $2.41 \mathrm{ppm}$ was approximately 1 : 17.45, which corresponded to $5.73 \%$ and $94.27 \%$ respectively. This result coincided with the results extracted from the HPLC chromatogram, where the peak labelled as Unknown 3, which eluted at a retention time of approximately 12.222 minutes, was also present in approximately the same amount. Hence Unknown 3 peak was most likely an anthraquinone containing a methoxy side group and it was present in approximately $6 \%$ of the total mass of the emodin working standard. NMR results also confirmed that the impurity peaks were not formed in situ on dissolving the standard in methanol.

Physcion (Fig. 5), which is an anthraquinone with a methoxy group, might be the impurity present in the working standard at a $6 \%$ percentage ratio.<smiles>COc1cc(O)c2c(c1)C(=O)c1cc(C)cc(O)c1C2=O</smiles>

Figure 5. Structure of Physcion

On cross-referencing the UV spectrum of the peak (Fig. 4D), with a documented spectrum of physcion, there seemed to be a positive match. Marković et al. ${ }^{28}$, reported the UV spectrum of physcion in methanol with the following $\lambda_{\max }: 225$, 253, 265, 286 and $433 \mathrm{~nm}$. Therefore this information was all pointing to the fact that the emodin working standard contained approximately $6 \%$ of physcion. The peaks referred to as Unknown 1 and 2 were present in too small a concentration to be picked up by NMR. Moreover it had already been established by the peak purity analysis that the peaks were not spectrally pure and hence could be a combination of a number of smaller peaks. It is most likely that these are process impurities that could not be separated during the extraction process.

\section{Validation}

The purpose of the purity assay HPLC method was to identify and quantify emodin in the presence of other impurities. In this regard, only the emodin peak was considered when evaluating validation parameters. The validation was conducted in accordance with ICH guideline Q2(R1) entitled 'Validation of analytical procedures' ${ }^{19}$. Six replicates were injected to the HPLC system. Validation of the HPLC assay method was performed at $287 \mathrm{~nm}$ and $436 \mathrm{~nm}$ for the emodin test concentration of 0.5 $\mathrm{mg} / \mathrm{mL}$. The proposed method was validated for specificity, linearity, range, accuracy, precision and solution stability.

\section{- System Suitability}

System suitability parameters were evaluated by injecting a standard solution of emodin of concentration $0.5 \mathrm{mg} / \mathrm{mL}$ in methanol for six consecutive times. The acceptance criteria were less than $2 \%$ relative standard deviation (RSD) for peak areas and peak retention times of the emodin peak, USP theoretical plates greater than 3000 and USP tailing factor smaller than 1.5.

\section{- $\quad$ Specificity}

Specificity was demonstrated by performing PDA peak purity analysis on the emodin peak using the Empower 2.0 software. The emodin reference and working standards were injected following a system suitability test, several blank injections and a bracketing standard at the end. Sections of the chromatograms that contained no noise were marked as 'baseline' noise to enable the software to measure the spectral baseline. Subsequently the software measured peak purity angles and threshold values. In cases where the peak purity angles were smaller than their respective threshold values, the peaks were considered to be spectrally pure. Spectral purity was confirmed for emodin and physcion but not for the first two unknown peaks. Nevertheless specificity was achieved.

\section{- Linearity}

The concentration range of the analytical procedure was identified through a linearity study. Linearity was evaluated for the emodin peak across a range of ten solutions of concentration ranging from 25 to $150 \%$ of the test concentration, namely 0.125 to $0.750 \mathrm{mg} / \mathrm{mL}$. Each solution was prepared by dilution from a stock standard solution of concentration $1.25 \mathrm{mg} / \mathrm{mL}$. Triplicate injections of each linearity solution were injected after the system suitability injections with adequate bracketing. The results were analysed at 287 and $436 \mathrm{~nm}$. The results of the statistical tests performed for the linearity determination are illustrated in Table. 5. Linearity was confirmed at both wavelengths; between 25 and $125 \%$ of the test concentration at $287 \mathrm{~nm}$ and 25 to $150 \%$ of the test concentration at $436 \mathrm{~nm}$. 
Table 5. Linearity results and ICH compliant acceptance criteria.

\begin{tabular}{|c|c|c|c|}
\hline Parameter & Results at $287 \mathrm{~nm}$ & Results at $436 \mathrm{~nm}$ & $\begin{array}{c}\text { ICH compliant } \\
\text { acceptance criteria }\end{array}$ \\
\hline Number of linearity solutions & 10 & 10 & $\geq 5$ \\
\hline $\begin{array}{l}\text { Range of area \%RSD of } \\
\text { triplicate injections }\end{array}$ & $0.01-0.76 \%$ & $0.03-0.79 \%$ & $<2.0 \%$ \\
\hline$\%$ RSD of response factor & $0.97 \%$ & $0.55 \%$ & $<2.0 \%$ \\
\hline Residual sum of squares & 23680275298 & 3101722671 & $\mathrm{n} / \mathrm{a}$ \\
\hline Range of \% response residual & $-1.56 \%$ to $0.64 \%$ & $-0.58 \%$ to $0.83 \%$ & $\leq 2.0 \%$ \\
\hline Residual standard deviation & 62822.9 & 19690.5 & $\mathrm{n} / \mathrm{a}$ \\
\hline $\begin{array}{l}\text { Relative residual standard } \\
\text { deviation }\end{array}$ & $0.54 \%$ & $0.25 \%$ & $\leq 2.0 \%$ \\
\hline Slope $\left(\mu \mathrm{v} . \mathrm{sec} \cdot \mathrm{mg}^{-1} \cdot \mathrm{mL}\right)$ & 30344150 & 17117041 & $\mathrm{n} / \mathrm{a}$ \\
\hline$y$ Intercept $\left(\mu \mathrm{v}^{*} \mathrm{sec}\right)$ & 170797 & 39451 & $\mathrm{n} / \mathrm{a}$ \\
\hline $\begin{array}{l}\% \text { y Intercept relative to } 0.5 \\
\mathrm{mg} / \mathrm{mL}\end{array}$ & $1.11 \%$ & $0.46 \%$ & $\leq 2.0 \%$ \\
\hline$r^{2}$ & 0.999892 & 0.999975 & $r \geq 0.998$ \\
\hline $\begin{array}{l}\text { Verified range of analytical } \\
\text { method }\end{array}$ & $25-125 \%$ & $25-150 \%$ & $80-120 \%$ \\
\hline
\end{tabular}

The limit of quantitation (LOQ) and limit of detection (LOD) concentration levels were not established since they are not required for assay methods as per the ICH Q2(R1) guideline ${ }^{19}$.

- Accuracy

The accuracy between the emodin reference standard, representing the accepted reference value, and the emodin working standard was measured across the range of the analytical procedure as determined through the linearity study. Accuracy was assessed using nine determinations over three concentration levels covering the specified range. The reference standard was prepared at $100 \%$ of the test concentration and the working standard was prepared in triplicate at 80,100 and $120 \%$ of the test concentration, corresponding to $0.4 \mathrm{mg} / \mathrm{mL}, 0.5$ $\mathrm{mg} / \mathrm{mL}$ and $0.6 \mathrm{mg} / \mathrm{mL}$ respectively. The reference standard and the nine working standard solutions were injected in triplicate following the system suitability and were adequately bracketed by standard. Accuracy was reported as percentage recovery. A summary of the results is illustrated in Table. 6. At the two wavelengths the minimum and maximum recovery values were within the recommended 98.0 to $102.0 \%$ range. The calculated $\%$ RSD of the overall percent recovery also satisfied the stated criteria, which is less than $2.0 \%$

Table 6. Results of the accuracy validation study for the emodin peak.

\begin{tabular}{|c|c|c|c|c|c|}
\hline \multicolumn{3}{|c|}{$287 \mathrm{~nm}$} & \multicolumn{3}{|c|}{$436 \mathrm{~nm}$} \\
\hline $\begin{array}{c}\text { Concentration of } \\
\text { Standard } \\
(\mathrm{mg} / \mathrm{mL})\end{array}$ & $\begin{array}{c}\text { Average } \\
\text { Recovery of } \\
\mathrm{n}=3 \text { replicates } \\
(\%)\end{array}$ & $\begin{array}{c}\text { Average RSD } \\
\text { of } n=3 \\
\text { replicates } \\
(\%)\end{array}$ & $\begin{array}{c}\text { Concentration of } \\
\text { Standard } \\
(\mathrm{mg} / \mathrm{mL})\end{array}$ & $\begin{array}{c}\text { Average } \\
\text { Recovery of } \\
\mathbf{n = 3} \text { replicates } \\
(\%)\end{array}$ & $\begin{array}{c}\text { Average RSD } \\
\text { of } n=3 \\
\text { replicates }(\%)\end{array}$ \\
\hline 0.406 & 99.38 & 0.80 & 0.407 & 98.90 & 0.81 \\
\hline 0.509 & 100.10 & 0.60 & 0.509 & 99.94 & 0.60 \\
\hline 0.612 & 98.48 & 0.37 & 0.612 & 98.77 & 0.38 \\
\hline Overall average & 99.32 & & Overall average & 99.20 & \\
\hline Overall RSD (\%) & 0.82 & & Overall RSD (\%) & 0.65 & \\
\hline
\end{tabular}

- Precision

\section{Repeatability}

Both the system precision and the overall repeatability were examined. System precision was measured by injecting one of the repeatability standards for six times consecutively. The mean peak area, retention time, theoretical plates or plate count and tailing for the emodin peaks and their respective
$\%$ RSD were measured. System precision was confirmed as at both wavelengths, the percentage relative standard deviations were less than $2.0 \%$ for all the parameters that were investigated.

To assess the overall repeatability, six standard preparations at $100 \%$ of the test concentration were prepared and analysed on the same chromatographic 
system. The six standard preparations were injected in triplicate following system suitability and adequate bracketing by a standard. The percentage recovery for each sample was calculated. The results of the six standards prepared at $100 \%$ of the test concentration are displayed in Table. 7. The \% RSD at both wavelengths were below $2.0 \%$ indicating that the technique applied for sample preparation entailed a very high degree of repeatability for the quantification of emodin. Moreover, an adequate recovery of the drug was observed with a $95 \%$ confidence interval (C.I.) that included the theoretical $100 \%$ recovery.

Table 7. Overall repeatability results for the emodin peak at 287 and $436 \mathrm{~nm}$.

\begin{tabular}{|l|c|c|}
\hline \multirow{2}{*}{ Solution } & $\mathbf{2 8 7} \mathbf{~ n m ~}$ & $\mathbf{4 3 6} \mathbf{~ n m}$ \\
\cline { 2 - 3 } & Mean \% Recovery of 3 injections & Mean \% Recovery of 3 injections \\
\hline Repeatability standard A & 100.32 & 100.14 \\
\hline Repeatability standard B & 100.56 & 100.42 \\
\hline Repeatability standard C & 99.42 & 99.27 \\
\hline Repeatability standard D & 99.90 & 99.76 \\
\hline Repeatability standard E & 100.70 & 100.50 \\
\hline Repeatability standard F & 99.89 & 99.73 \\
\hline Mean & $\mathbf{1 0 0 . 1 3}$ & $\mathbf{9 9 . 9 7}$ \\
\hline \%RSD & $\mathbf{0 . 4 8}$ & $\mathbf{0 . 4 7}$ \\
\hline 95\% C.I. & $\mathbf{9 9 . 6 2}$ to 100.64\% & $\mathbf{9 9 . 4 8}$ to 100.46\% \\
\hline
\end{tabular}

\section{Intermediate precision}

The intermediate precision was tested by running six freshly prepared standard replicates of the $100 \%$ test concentration on a different chromatographic system and on a different day (Day 2), and comparing them to the repeatability standards (Day 1). Each standard was injected in triplicate following a system suitability and adequately bracketed by a standard. The corresponding percentage recoveries were measured and the mean percentage recovery of the three replicate injections was measured. The \% RSD values that were obtained for the individual data sets and for the pooled data set are shown in Tables. 8 and 9. The individual and overall \%RSD values were less than $2.0 \%$ for both wavelengths indicating that the method showed good precision.

Table 8. Intermediate precision for the emodin peak at $287 \mathrm{~nm}$

\begin{tabular}{|c|c|c|c|}
\hline \multicolumn{2}{|c|}{ DAY 1} & \multicolumn{2}{|c|}{ DAY 2} \\
\hline Solution & $\begin{array}{c}\text { Mean \% } \\
\text { Recovery of } 3 \\
\text { replicate } \\
\text { injections }\end{array}$ & Solution & $\begin{array}{c}\text { Mean \% } \\
\text { Recovery of } 3 \\
\text { replicate } \\
\text { injections }\end{array}$ \\
\hline Repeatability standard A & 100.32 & Int. Precision Standard A & 99.51 \\
\hline Repeatability standard B & 100.56 & Int. Precision Standard B & 100.15 \\
\hline Repeatability standard C & 99.42 & Int. Precision Standard C & 100.73 \\
\hline Repeatability standard D & 99.90 & Int. Precision Standard D & 100.11 \\
\hline Repeatability standard E & 100.70 & Int. Precision Standard E & 99.19 \\
\hline Repeatability standard F & 99.89 & Int. Precision Standard F & 99.20 \\
\hline Mean & 100.13 & Mean & 99.82 \\
\hline$\%$ RSD & 0.48 & $\%$ RSD & 0.62 \\
\hline Variance & 0.23 & Variance & 0.38 \\
\hline 95\% C.I. & 99.63 to $100.64 \%$ & 95\% C.I. & 99.17 to $100.46 \%$ \\
\hline \multicolumn{2}{|c|}{$\begin{array}{l}\text { Calculations on pooled data sets (Day } 1 \text { and 2): } \\
\text { Overall Mean }\end{array}$} & \multicolumn{2}{|c|}{99.97} \\
\hline \multicolumn{2}{|l|}{ Overall \%RSD } & \multicolumn{2}{|l|}{0.59} \\
\hline \multicolumn{2}{|l|}{ Overall variance } & \multicolumn{2}{|l|}{0.34} \\
\hline \multicolumn{2}{|c|}{ Overall Confidence Interval at $95 \%$} & \multicolumn{2}{|c|}{99.78 to $100.17 \%$} \\
\hline
\end{tabular}


Table 9. Intermediate precision for the emodin peak at 436nm.

\begin{tabular}{|c|c|c|c|}
\hline \multicolumn{2}{|c|}{ DAY 1} & \multicolumn{2}{|c|}{ DAY 2} \\
\hline Solution & $\begin{array}{c}\text { Mean \% } \\
\text { Recovery of } 3 \\
\text { replicate } \\
\text { injections }\end{array}$ & Solution & $\begin{array}{c}\text { Mean \% } \\
\text { Recovery of } 3 \\
\text { replicate } \\
\text { injections }\end{array}$ \\
\hline Repeatability standard A & 100.14 & Int. Precision standard A & 99.45 \\
\hline Repeatability standard B & 100.42 & Int. Precision standard B & 100.04 \\
\hline Repeatability standard C & 99.27 & Int. Precision standard C & 100.61 \\
\hline Repeatability standard D & 99.76 & Int. Precision standard D & 100.10 \\
\hline Repeatability standard E & 100.50 & Int. Precision standard E & 99.10 \\
\hline Repeatability standard F & 99.73 & Int. Precision standard F & 99.08 \\
\hline Mean & 99.97 & Mean & 99.73 \\
\hline$\%$ RSD & 0.47 & $\%$ RSD & 0.62 \\
\hline Variance & 0.22 & Variance & 0.38 \\
\hline 95\% C.I. & 99.48 to $100.46 \%$ & 95\% C.I. & 99.08 to $100.38 \%$ \\
\hline \multicolumn{2}{|c|}{$\begin{array}{l}\text { Calculations on pooled data sets (Day } 1 \text { and 2): } \\
\text { Overall Mean }\end{array}$} & \multicolumn{2}{|c|}{99.85} \\
\hline \multicolumn{2}{|l|}{ Overall \%RSD } & \multicolumn{2}{|c|}{0.57} \\
\hline \multicolumn{2}{|l|}{ Overall variance } & \multicolumn{2}{|c|}{0.33} \\
\hline \multicolumn{2}{|c|}{ 95\% Overall Confidence Interval } & \multicolumn{2}{|c|}{99.66 to $100.04 \%$} \\
\hline
\end{tabular}

\section{Range}

The minimum specified range by $\mathrm{ICH}$ guideline $\mathrm{Q} 2(\mathrm{R} 1)$ of 80 to $120 \%$ of the emodin test concentration was demonstrated from the accuracy, linearity and precision data. The range of the assay method at $287 \mathrm{~nm}$ was demonstrated to be from 25 to $125 \%$ of the test concentration. The range of the assay method at $436 \mathrm{~nm}$ was found to be from 25 to $150 \%$ of the test concentration.

\section{Stability of solution}

Stability of solution was assessed for both the reference and working standards over a period of 24 hours. Storage temperature and light were examined for the purpose of this study. Stability was determined by comparing the response of the aged standards to the response obtained for the initial injection.

Part 1: Both standard and reference solutions were injected at the following time points: $0,2,4,6,8,10$, 12, and 24 hours. Duplicate injections were taken for each time point. The sequence was started off with a system suitability and was adequately bracketed. Both solutions showed no significant change in the total analyte composition, emodin retention time or emodin peak area. The \% RSD measured for the peak areas of emodin for both standards at 287 and $436 \mathrm{~nm}$ were all below $2 \%$.

Part 2: Aliquots of the standard and reference solutions were taken and stored for 24 hours in both clear and amber vials, both in a fridge $\left(4-8{ }^{\circ} \mathrm{C}\right)$ and at room temperature $\left(25^{\circ} \mathrm{C}\right)$. At both wavelengths, the percentage difference in the peak area of emodin was lower than $2.0 \%$ for all the factors that were investigated. Emodin was shown to be insensitive to light and stable at a temperature range of $4{ }^{\circ} \mathrm{C}$ to $25{ }^{\circ} \mathrm{C}$.

\section{Comparison of methods}

Only a few chromatographic methods have been developed for the exclusive determination of emodin in natural products. One such study was a HPLC method coupled to a diode array detector (DAD) to identify emodin in Tartary Buckwheat ${ }^{17}$. The method was optimized at a single detection wavelength of $436 \mathrm{~nm}$, and the emodin peak eluted at approximately 11.7 minutes. It also incorporated phosphoric acid in the mobile phase which limits the applicability of the method as phosphoric acid is incompatible with a number of detectors, namely MS. A second study determined emodin from Polygonum cuspidatum by HPLC-DAD ${ }^{18}$. This method incorporated a gradient elution with a run time of 25 minutes.

The method developed in this study is more rapid than the previously reported studies as the emodin peak eluted at approximately 6 minutes with a total run time of 15 minutes. This is extremely important as it utilizes less solvent and is therefore both time and cost effective. It incorporates TFA and formic acid in its mobile phase which allows use and interfacing with a large number of detectors. The method has been validated at dual wavelengths which enables the detection of emodin related substances. It is also linear over a concentration range of 0.125 to $0.625 \mathrm{mg} / \mathrm{mL}$, as well as highly accurate and precise. This method can also be applied in the determination and quantification of physcion as peak purity analysis showed that the physcion peak was spectrally pure. 


\section{Conclusion}

A simple, rapid, accurate and precise assay method for the HPLC analysis of emodin has been developed and validated in accordance to $\mathrm{ICH}$ criteria. All the validation criteria have been satisfied at $287 \mathrm{~nm}$ and $436 \mathrm{~nm}$. The method was also developed to be specific to emodin in the presence of related substances including process impurities such as physcion.

\section{References}

1 - European Council Directive 2004/24 EC of the European parliament and of the Council of 31 March 2004, amending as regards traditional herbal medicinal products, Directive 2001/83/EC on the Community code relating to medicinal products for human use.

2 - S. Tseng, H. Lee, L. Chen, C. Wu, C. Wang, Effects of three purgative decoctions on inflammatory mediators. J Ethnopharmacol., 2006,118-24.

3 - I. Izhaki, Emodin - a secondary metabolite with multiple ecological functions in higher plants. New Phytologist, 2002, 205-217.

4 - Y. Lee, O. Kang, J. Choi, Y. Oh, J. Keum, S. Kim, Synergistic effect of emodin in combination with ampicillin or oxacillin against methicillin-resistant Staphylococcus aureus. Pharm Biol, 2010,1285-1290.

5 - Y. Liu, N. Shen, C. Liu, Y. Lv, Immunosuppressive effects of emodin: an in vivo and in vitro study. Transplant Proc., 2009, 1837-9.

6 - J. Xue, W. Ding, Y. Liu, Anti-diabetic effects of emodin involved in the activation of PPARgamma on high-fat diet-fed and low dose of streptozotocin-induced diabetic mice. Fitoterapia, 2010, 173-7.

7 - W. Lee, S. Ku, D. Lee, T. Lee, B. JS, Emodin-6O- $\beta$-D--glucoside Inhibits High-GlucoseInduced Vascular Inflammation. Inflammation. 2014, 37(2):306-13

8 - G. Meng, Y. Liu, C. Lou, H. Yang, Emodin suppresses lipopolysaccharide-induced proinflammatory responses and NF-kappaB activation by disrupting lipid rafts in CD14negative endothelial cells. Br J Pharmacol, 2010, 1628-1644.

9 - J. Lai, J. Chang, C. Wen, Emodin induces a reactive oxygen species-dependent and ATMp53-Bax mediated cytotoxicity in lung cancer cells. Eur J Pharmacol, 2009, 1-9.

10 - C. Hsu, Y. Hsu, Y. Tsai, Emodin inhibits the growth of hepatoma cells: finding the common anti-cancer pathway using Huh7, Hep3B, and HepG2 cells. Biochem Biophys Res Commun, 2010, 473-478.

11 - J. Cai, X. Niu, Y. Chen, Q. Hu, G. Shi, H. Wu, J. Wang, J. Yi, Emodin-induced generation of reactive oxygen species inhibits RhoA activation to sensitize gastric carcinoma cells to anoikis. Neoplasia, 2008, 41-45.

12 - R. Räisänen, H. Björk, P. Hynninen, Twodimensional TLC separation and mass spectrometric identification of anthraquinones isolated from the fungus Dermocybe sanguinea. Z Naturforsch C, 2000, 55(3-4), 195-202.

13 - B. Jiang, X. Gao, K. Bi, XH. Chen, Simultaneous determination of anthraquinones in Liuwei'anxiao capsules by HPLC. Zhong Yao Cai., 2009, 32(6), 975-7.

14 - Y. Wang, X. Huang, Q. Liang, R. Fan, F. Qin, J. Luo, L. Gao, Simultaneous quantitation of seven anthraquinones in aqueous extract of rhubarb and analysis for absorption in cerebrospinal fluid of patients with traumatic brain injury using UPLC-PDA method. Journal of Medicinal Plants, 2011, 2879-2885.

15 - D. Yan, Y. Ma, Simultaneous quantification of five anthraquinones in rat plasma by highperformance liquid chromatography with fluorescence detection. Biomed Chromatogr., 2007, 21(5), 502-7.

16 - S. Mueller, M. Schmitt, W. Dekant, H. Stopper, J. Schlatter, P. Schreier, W. Lutz, Occurrence of emodin, chrysophanol and physcion in vegetables, herbs and liquors. Genotoxicity and anti-genotoxicity of the anthraquinones and of the whole plants. Food Chem Toxicol., 1999, 37(5), 481-91.

17 - L.-X. Peng, J.B. Wang, L.X. Hu, Rapid and simple method for the determination of emodin in tartary buckwheat (Fagopyrum tataricum) by high performance liquid chromatography coupled to a diode array detector. Journal of Agricultural and Food Chemistry, 2013, Issue 61, p. 854-857.

18 - H.M. Lu, Y. Liang, W. Ni, R. Man, Optimization of extraction and determination of emodin from Polygonum cuspidatum Sieb. et Zucc. products by HPLC-DAD. J. Cent. South Univ. Technol., 2006, 658-662.

19 - International Conference on Harmonization (ICH) guidelines ICH Q2(R1), Validation of analytical procedures: text and methodology, 2005.

20 - J. Mehta, Separation and characterization of anthraquinone derivatives from Cassia fistula using chromatographic and spectral techniques. Int. J. Chem. Sci., 2002, 306-316.

21 - S. Genovese, F. Tammaro, L. Menghini, G. Carlucci, F. Epifanoa and M. Locatellia, Comparison of three different extraction methods and HPLC determination of the anthraquinones aloe-emodine, emodine, rheine, chrysophanol and physcione in the bark of Rhamnus alpinus L. Rhamnaceae. Phytochem. Anal., 2010, 261-267

22 - Lu et al., Preparation of a nano emodin transfersome and study on its anti-obesity 
mechanism in adipose tissue of diet-induced obese rats, Journal of Translational Medicine, 2014, 12:72

23- J. Wang, H. Li, C. Jin, Y. Qu, X. Xiao, Development and validation of a UPLC method for quality control of rhubarb-based medicine: Fast simultaneous determination of five anthraquinone derivatives. Journal of Pharmaceutical and Biomedical Analysis, 2008, 765-770.

24 - Y-B Shi, Y-P Shi, Y-B Yang, G. Feng, Simultaneous determination of tetrehydropalmatine, magnolol, emodin and chrysophanol in Chinese Herbal Preparation by RP-HPLC-PDA. Chromatographia., 2007, 601606.

25 - R. Song, F. Xu, Z. Zhang, Y. Liu, H. Dong, Y. Tian, Structural elucidation of in vitro metabolites of emodin by liquid chromatography-tandem mass spectrometry. Biomedical Chromatography, 2008, 1230-1236.

26 - D. He, B. Chen, Q. Tian, S. Yao, Simultaneous determination of five anthraquinones in medicinal plants and pharmaceutical preparations by HPLC with fluorescence detection. Journal of Pharmaceutical and Biomedical Analysis, 2009, 1123-1127.

27 - D. Wang, G. Yang, X. Song, Determination of pKa values of anthraquinone compounds by capillary electrophoresis. Electrophoresis, 2001, 464-469.

28 - Z. Marković, N. Manojlović, S. Zlatanović, Electronic Absorption Spectra of Substituted Anthraquinones and Their Simulation Using ZINDO/S Method. Journal of the Serbian Society for Computational Mechanics, 2008, 7379.

29 - X. Chu, . Sun, R. Liu, Preparative isolation and purification of five compounds from the Chinese medicinal herb Polygonum cuspidatum Sieb. et Zucc by high-speed counter-current chromatography. J Chromatogr A., 2005, 1097(1-2):33-9.

30 -S. Guo, B. Feng, R. Zhu, J. Ma, Wang W., Preparative isolation of three anthraquinones from Rumex japonicus by High-Speed CounterCurrent Chromatography. 